ORIGINAL ARTICLE

\title{
Participation tactics of elite freestyle wrestlers in competition system in 2013-2016 Olympic cycle
}

\author{
Olha R. Zadorozhna ${ }^{1 \mathrm{ABCDE}}$, Yuriy A. Briskin ${ }^{1 \mathrm{ABCDE}}$, Maryan P. Pityn ${ }^{1 \mathrm{ABCDE}}$, Viktoriia Yu. Bohuslavska ${ }^{2 \mathrm{BCDE}}$, \\ Ivan G. Hlukhov ${ }^{3 \mathrm{BCDE}}$ \\ ${ }^{1}$ Department of Theory of Sports and Physical Culture, Lviv State University of Physical Culture named after Ivan \\ Bobers'kyy, Ukraine \\ ${ }^{2}$ Department of Theory and Methods of Sports, Vinnytsia State Pedagogical University named after Mykhailo \\ Kotsyubynsky, Ukraine \\ ${ }^{3}$ Department of Theory and Methodology of Physical Education, Kherson State University, Ukraine
}

Authors' Contribution: A - Study design; B - Data collection; C - Statistical analysis; D - Manuscript Preparation; E - Funds Collection.

\begin{abstract}
Background Tactics is one of the basic terms underlying the management of competitive activities of athletes. In and Study Aim freestyle wrestling, the participation tactics of athletes in the competition system is covered fragmentally and needs proper justification. The purpose of the study was to determine the features of the participation tactics of elite athletes in the competition system in freestyle wrestling during 2013-2016 Olympic cycle.

Material and This study analyzes the dynamics of performances and results of 24 elite freestyle wrestlers who won Methods gold, silver and bronze medals at the Games of XXXI Olympiad 2016 in Rio de Janeiro in different weight categories (four athletes in each of six weight categories). To do this, we used athletes' individual profiles on the United World Wrestling. Used an expert assessment devoted to the issues of tactics and tactical training. The experts $(n=8)$ were well educated ( 3 among them held Ph.D. diplomas) and experienced - 2 coaches of Ukrainian national team, and 1 athlete-national team's member. On average, experts had almost 10 years of experience in training wrestlers of different ages. The results were processed using Microsoft Excel software.

Results The volume of competition practice of elite athletes during 2013-2016 changed in each season. In the 2013 season, the average group number of competitions in which athletes participated was $3.84 \pm 2.06$, in $2014-3.50 \pm 1.79$. In the 2015 season, those indicators were the highest $-4.17 \pm 1.87$, but in 2016 they decreased to $3.71 \pm 1.52$. The participation tactics in the competition system in freestyle wrestling during the season and the four-year cycle differed depending on the dynamics of sports results. Four types of tactics used by the elite athletes in freestyle wrestling in 2013-2016 were identified: leadership holding, gradual improving of results, combined, leadership returning. It was found that during 20132016, most athletes (58.33-79.17\%) used a variety of tactics that involved performances in one Olympic weight category. In 2014 and 2015, some athletes (20.83 and $25.00 \%$, respectively) used different options in other weight categories, choosing one of them as a priority and one or two - as additional.

Conclusions: $\quad$ There are four types of participation tactics in the competition system in freestyle wrestling. In 2013-2016 Olympic cycle they included leadership holding, gradual increase of results, combined, leadership return. The main differences between types of tactics are the volume of competition practice, the dynamics of results, the choice of weight category. The most relevant was the type of tactics with performances exclusively in the Olympic weight category during four seasons.

Keywords: competitions, Olympic Games, calendar, season, results.
\end{abstract}

\section{Introduction}

Tactics is one of the basic terms in combat sports [1, 2]. In scientific papers there is a lot of definitions of this term. However, the main explanations were given by Keller [3] and Platonov [1]. According to Keller, it means a way of combination and implement of motor actions to solve competition problems, taking into account the rules and different conditions [3]. Platonov considers tactics as a theory and practice of organizing and conducting specialized activities to achieve goals in specific conflict situations on the basis of principles, schemes and norms of behavior [1]. According to Malkov and Gozhin [4], different interpretations of tactics are connected with the

o Olha R. Zadorozhna, Yuriy A. Briskin, Maryan P. Pityn,

Viktoriia Yu. Bohuslavska, Ivan G. Hlukhov, 2021

doi:10.15561/26649837.2021.0502 subjective perception of its defining link (classifier).

During the last ten years, in most papers in wrestling, tactics reflects athlete's ability to use proper technical action in the most adequate situation in the bout $[5,6]$. In our opinion, this interpretation does not allow to create a holistic view of all the features of tactics. Moreover, it enables to make conclusions about its transformation due to the current trends: complication of Olympic qualification system, changes of international and national calendars, competition rules, selection systems in national teams [7].

From this point of view, the most reasonable interpretation of tactics was given by Tumanyan [8]. $\mathrm{He}$ insists that tactics in wrestling is a kind of activity implemented on four levels: 1 - in special situation, 2 
- during the whole bout, 3 - during the tournament and its stages, $4-$ in the competition system. The principle position of the author is that at each level tactics is inseparable from the strategy. Both categories are types of activities of the coach and the athlete [8].

During the last five years, the main subjects of research in wrestling are the analysis of competition performance and changes caused by new competition rules [9-11], development of innovative means for technical and tactical training [12-15]; movement parameters of the elite athletes [16-19]. Other works are devoted to injury prevention during competition season [20-22], psychophysiological indicators of elite athletes during different events [23-25].

Based on the Tumanyan's ideas about four levels of tactics [8], we may conclude that the most studied are the first and second levels (performance in special situation and during the bout). Instead, the participation tactics in a specific event or competition system are covered fragmentally [5]. According to Kamayev et al., the participation tactics in the event aims at the appropriate distribution of effort at each stage by achieving the planned result [5]. The components of tactics at this level are the choice of weight category, determining the tactics for the bout against a particular opponent [5]. At the same time, the participation tactics in the competition system requires the implementation of the planned dynamics of competitive achievements and determines the strategy of four-year and annual cycle [8]. In our opinion, these issues are not represented in scientific literature properly. Some researches described competitive achievements of elite wrestlers within few Olympic cycles [17, 26]. However, the obtained data allowed them to predict the effectiveness of wrestlers' competitive activities in the Olympic arena and to create the models of their training [16]. We believe that the dynamics of athletes' performances during the season or Olympic cycle might be used for identifying the types of participation tactics in the competition system. Our previous papers confirmed this possibility in fencing [27].

Despite the great attention to elite wrestlers' tactics in modern papers, none of the studies revealed tactical schemes of their participation in different events. There are still no data on the types of tactics of weight category choice during the season and the whole Olympic cycle.

Hypothesis. We assumed that the participation tactics of elite freestyle wrestlers may differ depending on the dynamics of sports results in official international tournaments not only during the seasons, but in general during the Olympic cycle. According to our assumption, the differences between the types of participation tactics in the competition system may also consist in various types of the weight category choice during one season and the whole Olympic cycle.

The purpose of the study was to determine the features of the participation tactics of elite athletes in the competition system in freestyle wrestling during 20132016 Olympic cycle.

\section{Materials and methods}

Participants

This study analyzes the dynamics of performances and results of 24 elite freestyle wrestlers who won gold, silver and bronze medals at the Games of XXXI Olympiad 2016 in Rio de Janeiro in different weight categories (four athletes in each of six weight categories). To do this, we used athletes' individual profiles on the United World Wrestling (UWW) website [28].

Study design

The next step included an expert assessment devoted to the issues of tactics and tactical training (February August 2019). The experts $(\mathrm{n}=8)$ were well educated (3 among them held Ph.D. diplomas) and experienced - 2 coaches of Ukrainian national team, and 1 athletenational team's member. On average, experts had almost 10 years of experience in training wrestlers of different ages.

The questionnaires were administered to the experts in two different ways. 5 questionnaires were administered in a paper form and filled under the supervision of the researcher. The other 3 questionnaires were distributed by e-mail. Each expert was asked to rank the components of tactical training in each section. The number of components in sections ranged from 5 to 10 . Rank 1 was always considered the most significant. The highest rank indicated the least important component (eg. in section with 9 components, rank 9 was the least important).

In order to confirm the accuracy of the answers, the concordance coefficient was determined in each group of experts (W). The statistical validity of the concordance coefficient was verified using the $\chi 2$ criterion (Pearson's chi-squared test). According to Shiian et al. [29], the critical value of the concordance coefficient was defined as $\mathrm{W}=0.5$. Therefore, at $0.69>\mathrm{W} \geq 0.5$, the agreement of experts' opinions was evaluated as average, at $\mathrm{W} \geq 0.7$ as high (strong), and at $\mathrm{W}<0.5$ as low (weak).

The next step of the research (September 2020 - January 2021) was analyzes of 24 elite wrestlers' individual profiles on UWW [28]. In total, we analyzed the participation and results of 24 freestyle wrestlers, representatives of all weight categories, during the Olympic cycle 2013-2016. To make conclusions on their participation tactics our attention was focused on such indicators:

- the number of competitions in which each athlete participated during the season (absolute value and percentage of the maximum number of competitions for his or her weapon);

- the results at the main competitions of the season: during the 1st-3rd seasons - at the World Championships (WCh), in the 4 th - at the Games of XXXI Olympiad);

- the number of competitions in which the athlete won medals during the season (percentage of the total number of competitions in which he participated during the season, hereinafter - "indicator of medal achievements");

- "average place" - the average mean of all places that 
athletes took in competitions during the season;

- the ratio of competitions of different age categories in which the athlete took part during the season (Cadets, Juniors, Seniors);

- the highest and lowest result during the season (place in competitions);

- the number of competitions that the athlete finished at different stages $-1 / 4,1 / 8$, etc. (percentage of the total number of competitions in which the athlete participated during the season);

- $\quad$ peculiarities of the Olympic qualification - whether the athlete or another representative of the NOC of the country succeeded personally; in which of the four stages of the Olympic qualification system it was done.

Additionally, we took into account the range of weight categories in which each wrestler performed during the four seasons 2013-2016, and the number of competitions held in the particular weight category (if the athlete competed in few categories).

Statistical Analysis

All obtained data were statistically processed using the STATISTIKA 10.0 software and Microsoft Excel 2016. The data are represented as the average mean \pm standard deviation (SD), Max - maximum in the season; Min - the minimum in the season. ShapiroWilk's test was used to check normality of distribution of the indicators of competition practice and results of 24 elite freestyle wrestlers during four seasons within 2013-2016 Olympic cycle. This test was also used to check normality of distribution of the same indicators in three groups of athletes who used different types of participation tactics in 2013-2016 Olympic cycle. In order to determine the significance of differences of the results in each group during the whole Olympic cycle 2013-2016 we used parametric and non-parametric tests. In case of normal distribution of indicators, we used the single-factor analysis of variance ANOVA. In case of absence of normal distribution, we used non-parametric Kruskal-Wallis H-test. If the indicators in one season were normally distributed, but in other seasons there was absence of normal distribution, we used both tests ANOVA and Kruskal-Wallis H-test. Method Bonferroni was used for correction in both tests. The level of statistical significance of differences was set at $\mathrm{p} \leq 0.05$.

\section{Results}

We took into account expert's opinion on three questions. We discovered that control of elite wrestlers' tactics and tactical preparedness should be based on the analysis of competitive performance and results in particular competitions (average ranks 1.33 and 1.75 respectively, $\mathrm{W}=0.26, \mathrm{p}<0.05$ ). The main component of tactical training for elite wrestlers is the improvement of tactical thinking: how to trick an opponent and make him make a mistake during the fragment of the bout, the whole match or at different stages of competitions, how to choose proper tactics for competitions of different levels such as World Cups, World and Continental Championships,
The Games of Olympiad (average rank 1.50, $\mathrm{W}=0.74$, $\mathrm{p}<0.05$ ). We also discovered that $100.0 \%$ of experts insist on the differentiation of tactical training for individual and team events. The results of this part of research were discussed in our previous papers [30].

Features of the competition system are regulated by the "International Wrestling Rules" [28]. Analysis of the UWW competition calendars for "Seniors" age category indicated that during the 2013-2016 Olympic cycle, freestyle wrestlers could participate in 44-45 tournaments in each season. It was established that the dynamics of elite wrestlers' performances during 2013-2016 changed in waves. The average group results at the main competitions and the indicators of medal achievements grew gradually every season. The "average place" (arithmetic mean of all places), the highest and lowest results increased during the $1^{\text {st }}-3^{\text {rd }}$ seasons, but in the $4^{\text {th }}$ they decreased slightly compared to the $3^{\text {rd }}$ (Table 1). Table 1 represents KruskalWallis and ANOVA p-values for each of six indicators, with statistical significance $a=0.05$.

The analysis of the obtained results allowed to assert the absence of a normal distribution in majority of indicators. The Kruskal-Wallis H-test showed that the results during four seasons are significantly equal at $p \leq 0.05$. Instead, the ANOVA test indicated that the highest results in each season and the results at the main competitions (WCh) were significantly different at $\mathrm{p} \leq$ 0.05 . According to our hypothesis, it is connected with the specifics of competition practice and results dynamics of elite athletes who used different types of participation tactics in each of four seasons and the whole Olympic cycle.

That is why the next step of our research aimed to compare those data in each group of wrestlers. The first group $(n=7)$ included representatives of all weight categories, which showed high results in each season. Their participation tactics in the competition system in 2013-2016 was defined as leadership holding (Table 2).

During the $1^{\text {st }}$ and $2^{\text {nd }}$ seasons, athletes in this group increased the amount of competitive practice. In $3^{\text {rd }}$ season, this indicator remained stable, in the $4^{\text {th }}-$ decreased again. The results at the main competitions of the season, the indicators of medal achievements, the arithmetic mean of all places were consistently high in each season. An exception in this group of athletes was the representative of the Russian Federation A. G., who for reasons unknown to us did not participate in the WCh 2013 and 2014, but showed high results at other tournaments, including the European Championships (ECh). The Kruskal-Wallis p-values showed that there are no significant differences between the means of any indicator at statistical significance $p \leq 0.05$. It confirmed that athletes' results during four seasons were almost equal and high (as they were leaders).

The second group $(\mathrm{n}=10)$ included representatives of all weight categories, whose results gradually increased in each season (they were the highest in 2016). The number of competitions in which athletes participated gradually increased, except for the $2^{\text {nd }}$ season, in which the number 
Table 1. The dynamics of competition practice and results of elite freestyle wrestlers in 2013-2016 Olympic cycle ( $\mathrm{n}=$ 24)

\begin{tabular}{|c|c|c|c|c|c|c|c|}
\hline \multirow{2}{*}{ Indicators } & & \multicolumn{4}{|l|}{ Seasons } & \multirow{2}{*}{$\begin{array}{l}\text { ANOVA } \\
\text { p-value }\end{array}$} & \multirow{2}{*}{$\begin{array}{l}\text { KW } \\
\text { p-value }\end{array}$} \\
\hline & & 2013 & 2014 & 2015 & 2016 & & \\
\hline \multirow{3}{*}{$\begin{array}{l}\text { The number } \\
\text { of events }\end{array}$} & Mean \pm SD & $3.84 \pm 2.06$ & $3.50 \pm 1.79$ & $4.17 \pm 1.87$ & $3.71 \pm 1.52$ & \multirow{3}{*}{0.660} & \multirow{3}{*}{0.706} \\
\hline & $\begin{array}{l}\text { Range } \\
\text { (Min - Max) }\end{array}$ & $1-8$ & $1-6$ & $1-7$ & $1-7$ & & \\
\hline & $\begin{array}{l}\text { Shapiro-Wilk } \\
\text { p-value }\end{array}$ & 0.231 & 0.013 & 0.097 & 0.326 & & \\
\hline \multirow{3}{*}{ AP } & Mean \pm SD & $4.40 \pm 3.15$ & $4.16 \pm 3.46$ & $2.91 \pm 1.91$ & $3.25 \pm 2.67$ & \multirow{3}{*}{0.262} & \multirow{3}{*}{0.436} \\
\hline & $\begin{array}{l}\text { Range } \\
\text { (Min - Max) }\end{array}$ & $1.00-11.50$ & $1.00-12.00$ & $1.00-7.67$ & $1.00-13.00$ & & \\
\hline & $\begin{array}{l}\text { Shapiro-Wilk } \\
\text { p-value }\end{array}$ & 0.013 & 0.004 & 0.0009 & 0.00004 & & \\
\hline \multirow{3}{*}{$\begin{array}{l}\text { The highest } \\
\text { result }\end{array}$} & Mean \pm SD & $1,68 \pm 1.25$ & $2.60 \pm 3.03$ & $1.30 \pm 0.70$ & $1.33 \pm 0.64$ & \multirow{3}{*}{$0.044^{*}$} & \multirow{3}{*}{0.373} \\
\hline & $\begin{array}{l}\text { Range } \\
\text { (Min - Max) }\end{array}$ & $1-5$ & $1-12$ & $1-3$ & $1-3$ & & \\
\hline & $\begin{array}{l}\text { Shapiro-Wilk } \\
\text { p-value }\end{array}$ & 0.0003 & 0.0003 & 0.0004 & 0.0003 & & \\
\hline \multirow{3}{*}{$\begin{array}{l}\text { The lowest } \\
\text { result }\end{array}$} & Mean \pm SD & $10.16 \pm 10.20$ & $7.00 \pm 6.46$ & $5.83 \pm 5.25$ & $5.96 \pm 5.54$ & \multirow{3}{*}{0.175} & \multirow{3}{*}{0.345} \\
\hline & $\begin{array}{l}\text { Range } \\
\text { (Min - Max) }\end{array}$ & $1-37$ & $1-20$ & $1-21$ & $1-20$ & & \\
\hline & $\begin{array}{l}\text { Shapiro-Wilk } \\
\text { p-value }\end{array}$ & 0.0005 & 0.002 & 0.0006 & 0.0001 & & \\
\hline \multirow{3}{*}{ IMA, \% } & Mean \pm SD & $67.21 \pm 31.40$ & $\begin{array}{l}70.08 \pm \\
39.86\end{array}$ & $\begin{array}{l}83.70 \pm \\
23.18\end{array}$ & $\begin{array}{l}83.56 \pm \\
21.06\end{array}$ & \multirow{3}{*}{0.137} & \multirow{3}{*}{0.199} \\
\hline & $\begin{array}{l}\text { Range } \\
\text { (Min - Max) }\end{array}$ & $0-100$ & $0-100$ & $28.57-100$ & $33.33-100$ & & \\
\hline & $\begin{array}{l}\text { Shapiro-Wilk } \\
\text { p-value }\end{array}$ & 0.022 & 0.001 & 0.001 & 0.001 & & \\
\hline \multirow{3}{*}{$\begin{array}{l}\text { Results at } \\
\text { the main } \\
\text { competitions }\end{array}$} & Mean \pm SD & $8.70 \pm 9.38$ & $4.64 \pm 6.50$ & $3.94 \pm 5.51$ & $2.25 \pm 0.85$ & \multirow{3}{*}{$0.025^{*}$} & \multirow{3}{*}{0.260} \\
\hline & $\begin{array}{l}\text { Range } \\
\text { (Min - Max) }\end{array}$ & $1-30$ & $1-20$ & $1-21$ & $1-3$ & & \\
\hline & $\begin{array}{l}\text { Shapiro-Wilk } \\
\text { p-value }\end{array}$ & 0.023 & 0.0002 & 0.001 & 0.0005 & & \\
\hline
\end{tabular}

Note. Mean - arithmetic mean; SD - standard deviation; Max - the maximum in the season; Min - the minimum in the season; AP - "average place", the average mean of all places that athletes achieved in competitions during the season; IMA, "indicator of medal achievements" - the ratio of events in which athletes won medals to the total number of tournaments held by them during the season (\%); the highest/ the lowest results - the highest/ the lowest places which athletes achieved during the season; results at the main competitions - the places taken by athletes at the World Championships in $1^{\text {st }}-3^{\text {rd }}$ seasons (2013-2015), and the Games of XXXI Olympiads the $4^{\text {th }}$ season (2016); * - significantly different indicators ( $p \leq 0.05)$.

of competitions was lower than in the $1^{\text {st }}$ one. Indicators of medal achievements, results at $\mathrm{WCh}$, the arithmetic mean of all places also gradually increased in each season, but the largest increase was found in 2016 (Table $3)$. Interestingly, most athletes $(n=7)$ missed a different number of seasons (from one to three). Three athletes did not take part in the 2013-2015 WCh, but performed in other official international events.

The Kruskal-Wallis and ANOVA p-values showed that there was no significant difference between majority of indicators in the second group. Exception was found in results at the main competitions where significant difference was present at level $\mathrm{p} \leq 0.05$.

The third group $(n=6)$ included wrestlers who improved their results during the $1^{\text {st }}$ and $2^{\text {nd }}$ seasons, and kept them at a high level in the following ones. Their tactics was described as combined. As in other groups, two athletes missed the 2013 and 2014 WCh (Table 4).

Kruskal-Wallis and ANOVA p-values showed that in the third group there was no significant difference between 
Table 2. The dynamics of competition practice and results of elite freestyle wrestlers who used tactics of leadership holding in 2013-2016 Olympic cycle $(n=7)$

\begin{tabular}{|c|c|c|c|c|c|c|c|}
\hline \multirow{2}{*}{ Indicators } & & \multicolumn{4}{|l|}{ Seasons } & \multirow{2}{*}{$\begin{array}{l}\text { ANOVA } \\
\text { p-value }\end{array}$} & \multirow{2}{*}{$\begin{array}{l}\text { KW } \\
\text { p-value }\end{array}$} \\
\hline & & 2013 & 2014 & 2015 & 2016 & & \\
\hline \multirow{3}{*}{$\begin{array}{l}\text { The number } \\
\text { of events }\end{array}$} & Mean \pm SD & $3.71 \pm 2.29$ & $4.00 \pm 1.47$ & $4.00 \pm 1.72$ & $2.86 \pm 1.68$ & \multirow{3}{*}{0.653} & \multirow{3}{*}{0.528} \\
\hline & $\begin{array}{l}\text { Range } \\
\text { (Min - Max) }\end{array}$ & $1-7$ & $2-6$ & $2-7$ & $1-6$ & & \\
\hline & $\begin{array}{l}\text { Shapiro-Wilk } \\
\text { p-value }\end{array}$ & 0.519 & 0.925 & 0.658 & 0.277 & & \\
\hline \multirow{3}{*}{ AP } & Mean \pm SD & $1.90 \pm 0.71$ & $1.82 \pm 1.17$ & $1.84 \pm 1.09$ & $2.17 \pm 1.43$ & \multirow{3}{*}{0.885} & \multirow{3}{*}{0.808} \\
\hline & $\begin{array}{l}\text { Range } \\
\text { (Min - Max) }\end{array}$ & $1.00-3.00$ & $1.00-4.00$ & $1.00-3.43$ & $1.00-5.00$ & & \\
\hline & $\begin{array}{l}\text { Shapiro-Wilk } \\
\text { p-value }\end{array}$ & 0.932 & 0.009 & 0.031 & 0.086 & & \\
\hline \multirow{3}{*}{$\begin{array}{l}\text { The highest } \\
\text { result }\end{array}$} & Mean \pm SD & $1.00 \pm 0.00$ & $1.00 \pm 0.00$ & $1.00 \pm 0.00$ & $1.29 \pm 0.76$ & \multirow{3}{*}{0.434} & \multirow{3}{*}{0.414} \\
\hline & $\begin{array}{l}\text { Range } \\
\text { (Min - Max) }\end{array}$ & $1-1$ & $1-1$ & $1-1$ & $1-3$ & & \\
\hline & $\begin{array}{l}\text { Shapiro-Wilk } \\
\text { p-value }\end{array}$ & 0.998 & 0.998 & 0.998 & 0.001 & & \\
\hline \multirow{3}{*}{$\begin{array}{l}\text { The lowest } \\
\text { result }\end{array}$} & Mean \pm SD & $4.00 \pm 2.94$ & $3.00 \pm 2.73$ & $3.29 \pm 3.08$ & $3.29 \pm 3.15$ & \multirow{3}{*}{0.881} & \multirow{3}{*}{0.682} \\
\hline & $\begin{array}{l}\text { Range } \\
\text { (Min - Max) }\end{array}$ & $1-9$ & $1-8$ & $1-8$ & $1-10$ & & \\
\hline & $\begin{array}{l}\text { Shapiro-Wilk } \\
\text { p-value }\end{array}$ & 0.274 & 0.016 & 0.036 & 0.019 & & \\
\hline \multirow{3}{*}{ IMA, \% } & Mean \pm SD & $\begin{array}{l}92.72 \pm \\
9.23\end{array}$ & $\begin{array}{l}93.33 \pm \\
13.61\end{array}$ & $\begin{array}{l}92.35 \pm \\
13.88\end{array}$ & $90.48 \pm 18.90$ & \multirow{3}{*}{0.967} & \multirow{3}{*}{0.938} \\
\hline & $\begin{array}{l}\text { Range } \\
\text { (Min - Max) }\end{array}$ & $80.00-100$ & $66.67-100$ & $71.43-100$ & $50.00-100$ & & \\
\hline & $\begin{array}{l}\text { Shapiro-Wilk } \\
\text { p-value }\end{array}$ & 0.019 & 0.0008 & 0.002 & 0.002 & & \\
\hline \multirow{3}{*}{$\begin{array}{l}\text { Results at } \\
\text { the main } \\
\text { competitions }\end{array}$} & Mean \pm SD & $1.75 \pm 0.96$ & $1.75 \pm 0.89$ & $2.00 \pm 0.98$ & $1.57 \pm 0.79$ & \multirow{3}{*}{0.817} & \multirow{3}{*}{0.830} \\
\hline & $\begin{array}{l}\text { Range } \\
\text { (Min - Max) }\end{array}$ & $1-3$ & $1-3$ & $1-3$ & $1-3$ & & \\
\hline & $\begin{array}{l}\text { Shapiro-Wilk } \\
\text { p-value }\end{array}$ & 0.382 & 0.068 & 0.023 & 0.028 & & \\
\hline
\end{tabular}

Note. Mean - arithmetic mean; SD - standard deviation; Max - the maximum in the season; Min - the minimum in the season; AP - "average place", the average mean of all places that athletes achieved in competitions during the season; IMA, "indicator of medal achievements" - the ratio of events in which athletes won medals to the total number of tournaments held by them during the season (\%); the highest/ the lowest results - the highest/ the lowest places which athletes achieved during the season; results at the main competitions - the places taken by athletes at the World Championships in $1^{\text {st }}-3^{\text {rd }}$ seasons (2013-2015), and the Games of XXXI Olympiads the $4^{\text {th }}$ season (2016).

the number of events, indicator of medal achievements, results at the main competitions. Instead, the average place and the lowest result were significantly different at level $p \leq 0.05$. It confirmed that athletes of the third group combined tactics of gradual increase of results (in the $1^{\text {st }}$ and $2^{\text {nd }}$ seasons) and leadership holding (in the $3^{\text {rd }}$ and $4^{\text {th }}$ ).

Additionally, we should describe the participation tactics of the representative of Georgia G. P. We didn't include him in previous groups, because his tactics was defined as leadership return. In all seasons (excepting the $2^{\text {nd }}$ ), he showed consistently high results in major competitions, winning bronze medals. Medal achievements were also high $-75.00-100 \%$ (except in 2014, where he did not win any awards). The wrestler finished the $1^{\text {st }}$ season as the leader, winning a bronze medal at the WCh. In the $2^{\text {nd }}$ season, he lost the lead, but in 2015-2016 managed not only to regain it, but also to keep it.

A separate component of wrestlers' participation in the competition system is the choice of weight category (WC) [16]. Thus, the next step of the study was to identify its features during each season and the overall Olympic cycle of 2013-2016 (Table 5). 
Table 3. The dynamics of competition practice and results of elite freestyle wrestlers who used tactics of who used tactics of gradual increase of results in 2013-2016 Olympic cycle $(n=10)$

\begin{tabular}{|c|c|c|c|c|c|c|c|}
\hline \multirow{2}{*}{ Indicators } & & \multicolumn{4}{|l|}{ Seasons } & \multirow{2}{*}{$\begin{array}{l}\text { ANOVA } \\
\text { p-value }\end{array}$} & \multirow{2}{*}{$\begin{array}{l}\text { KW } \\
\text { p-value }\end{array}$} \\
\hline & & 2013 & 2014 & 2015 & 2016 & & \\
\hline \multirow{3}{*}{$\begin{array}{l}\text { The number } \\
\text { of events }\end{array}$} & $\begin{array}{l}\text { Mean } \pm \text { SD } \\
\text { Range }\end{array}$ & $3.67 \pm 2.16$ & $3.13 \pm 1.89$ & $3.78 \pm 2.44$ & $4.20 \pm 1.69$ & \multirow{3}{*}{0.745} & \multirow{3}{*}{0.693} \\
\hline & (Min - Max) & $1-7$ & $1-5$ & $1-7$ & $2-7$ & & \\
\hline & $\begin{array}{l}\text { Shapiro-Wilk } \\
\text { p-value }\end{array}$ & 0.998 & 0.031 & 0.065 & 0.556 & & \\
\hline \multirow{3}{*}{ AP } & Mean \pm SD & $5.04 \pm 2.42$ & $5.10 \pm 3.53$ & $4.29 \pm 2.31$ & $4.34 \pm 3.64$ & \multirow{3}{*}{0.921} & \multirow{3}{*}{0.775} \\
\hline & $\begin{array}{l}\text { Range } \\
\text { (Min - Max) }\end{array}$ & $2.25-8.20$ & $\begin{array}{l}1.50- \\
12.00\end{array}$ & $1.50-7.67$ & $1.25-13.00$ & & \\
\hline & $\begin{array}{l}\text { Shapiro-Wilk } \\
\text { p-value }\end{array}$ & 0.537 & 0.279 & 0.189 & 0.027 & & \\
\hline \multirow{3}{*}{$\begin{array}{l}\text { The highest } \\
\text { result }\end{array}$} & $\begin{array}{l}\text { Mean } \pm \text { SD } \\
\text { Range }\end{array}$ & $2.00 \pm 1.55$ & $3.50 \pm 3.85$ & $1.78 \pm 0.97$ & $1.40 \pm 0.70$ & \multirow{3}{*}{0.204} & \multirow{3}{*}{0.610} \\
\hline & (Min - Max) & $1-5$ & $1-12$ & $1-3$ & $1-3$ & & \\
\hline & $\begin{array}{l}\text { Shapiro-Wilk } \\
\text { p-value }\end{array}$ & 0.019 & 0.008 & 0.004 & 0.0008 & & \\
\hline \multirow{3}{*}{$\begin{array}{l}\text { The lowest } \\
\text { result }\end{array}$} & $\begin{array}{l}\text { Mean } \pm \text { SD } \\
\text { Range }\end{array}$ & $11.17 \pm 8.91$ & $8.75 \pm 7.27$ & $8.44 \pm 7.14$ & $8.90 \pm 7.16$ & \multirow{3}{*}{0.908} & \multirow{3}{*}{0.774} \\
\hline & (Min - Max) & $3-25$ & $3-20$ & $2-21$ & $2-20$ & & \\
\hline & $\begin{array}{l}\text { Shapiro-Wilk } \\
\text { p-value }\end{array}$ & 0.231 & 0.021 & 0.035 & 0.062 & & \\
\hline \multirow{3}{*}{ IMA, \% } & Mean \pm SD & $\begin{array}{l}51.87 \pm \\
34.74\end{array}$ & $\begin{array}{l}55.83 \pm \\
47.67\end{array}$ & $\begin{array}{l}73.54 \pm \\
32.11\end{array}$ & $78.05 \pm 23.22$ & \multirow{3}{*}{0.366} & \multirow{3}{*}{0.472} \\
\hline & $\begin{array}{l}\text { Range } \\
\text { (Min - Max) }\end{array}$ & $0-100$ & $0-100$ & $28.57-100$ & $33.33-100$ & & \\
\hline & $\begin{array}{l}\text { Shapiro-Wilk } \\
\text { p-value }\end{array}$ & 1 & 0.017 & 0.008 & 0.116 & & \\
\hline \multirow{3}{*}{$\begin{array}{l}\text { Results at } \\
\text { the main } \\
\text { competitions }\end{array}$} & Mean \pm SD & $12.33 \pm 5.86$ & $\begin{array}{l}11.00 \pm \\
12.73\end{array}$ & $\begin{array}{l}13.67 \pm \\
8.08\end{array}$ & $2.70 \pm 0.48$ & \multirow{3}{*}{$0.001^{*}$} & \multirow{3}{*}{$0.020 *$} \\
\hline & $\begin{array}{l}\text { Range } \\
\text { (Min - Max) }\end{array}$ & $8-19$ & $2-20$ & $5-21$ & $2-3$ & & \\
\hline & $\begin{array}{l}\text { Shapiro-Wilk } \\
\text { p-value }\end{array}$ & 0.574 & 1 & 0.999 & 0.0003 & & \\
\hline
\end{tabular}

Note. Mean - arithmetic mean; SD - standard deviation; Max - the maximum in the season; Min - the minimum in the season; AP - "average place", the average mean of all places that athletes achieved in competitions during the season; IMA, "indicator of medal achievements" - the ratio of events in which athletes won medals to the total number of tournaments held by them during the season (\%); the highest/ the lowest results - the highest/ the lowest places which athletes achieved during the season; results at the main competitions - the places taken by athletes at the World Championships in $1^{\text {st }} 3^{\text {rd }}$ seasons (2013-2015), and the Games of XXXI Olympiads the $4^{\text {th }}$ season (2016); * significantly different indicators $(p \leq 0.05)$.

It was established that in 2013 the majority of athletes performed in one Olympic WC. One athlete (M. I. I., Republic of Uzbekistan) held $50.00 \%$ of tournaments in two Olympic WCs, one of which was lighter than the one in which he competed in subsequent seasons. Instead, another representative of this country, I. N., took part in competitions in the priority Olympic $(75.00 \%$ of tournaments) and additional non-Olympic WC (25.00\%), which was heavier than the priority. Five wrestlers completely missed the 2013 season. One of them (R.H.) competed exclusively in the age category "Cadets".
In the 2014 season, most athletes preferred to perform in one Olympic WC. Four more chose the Olympic WC as a priority (66.67-75.00\% of tournaments), and used the non-Olympic WC as an additional (25.00-33.33\% of events). Three of them competed in the non-Olympic WC, which was heavier than the priority Olympic. At the same time Sh. Sh. (Republic of Azerbaijan) competed in the additional non-Olympic WC, which was much lighter than the priority ("96 kg" and "70 kg", respectively). $\mathrm{H}$. A. (Republic of Azerbaijan) performed in the priority non-Olympic WC. In addition, he used the Olympic WC, 
Table 4. The dynamics of competition practice and results of elite freestyle wrestlers who used combined tactics in 2013-2016 Olympic cycle $(n=6)$

\begin{tabular}{|c|c|c|c|c|c|c|c|}
\hline \multirow{2}{*}{ Indicators } & & \multicolumn{4}{|l|}{ Seasons } & \multirow{2}{*}{$\begin{array}{l}\text { ANOVA } \\
\text { p-value }\end{array}$} & \multirow{2}{*}{$\begin{array}{l}\text { KW } \\
\text { p-value }\end{array}$} \\
\hline & & 2013 & 2014 & 2015 & 2016 & & \\
\hline \multirow{3}{*}{$\begin{array}{l}\text { The number } \\
\text { of events }\end{array}$} & $\begin{array}{l}\text { Mean } \pm \text { SD } \\
\text { Range }\end{array}$ & $4.20 \pm 2.28$ & $4.20 \pm 1.92$ & $4.83 \pm 1.33$ & $3.67 \pm 0.52$ & \multirow{3}{*}{0.663} & \multirow{3}{*}{0.439} \\
\hline & (Min - Max) & $2-8$ & $1-6$ & $3-6$ & $3-4$ & & \\
\hline & $\begin{array}{l}\text { Shapiro-Wilk } \\
\text { p-value }\end{array}$ & 0.277 & 0.271 & 0.079 & 0.006 & & \\
\hline \multirow{3}{*}{ AP } & $\begin{array}{l}\text { Mean } \pm \text { SD } \\
\text { Range }\end{array}$ & $7.27 \pm 3.81$ & $4.64 \pm 4.03$ & $2.29 \pm 0.64$ & $2.92 \pm 1.36$ & \multirow{3}{*}{$0.035^{*}$} & \multirow{3}{*}{$0.041^{*}$} \\
\hline & (Min - Max) & $3.33-11.50$ & $1.00-11.50$ & $1.25-3.17$ & $1.50-5.00$ & & \\
\hline & $\begin{array}{l}\text { Shapiro-Wilk } \\
\text { p-value }\end{array}$ & 0.346 & 0.167 & 0.979 & 0.539 & & \\
\hline \multirow{3}{*}{$\begin{array}{l}\text { The highest } \\
\text { result }\end{array}$} & $\begin{array}{l}\text { Mean } \pm \text { SD } \\
\text { Range }\end{array}$ & $2.20 \pm 1.64$ & $1.80 \pm 1.10$ & $1.00 \pm 0.00$ & $1.33 \pm 0.52$ & \multirow{3}{*}{0.224} & \multirow{3}{*}{0.198} \\
\hline & (Min - Max) & $1-5$ & $1-3$ & $1-1$ & $1-2$ & & \\
\hline & $\begin{array}{l}\text { Shapiro-Wilk } \\
\text { p-value }\end{array}$ & 0.077 & 0.019 & 1 & 0.006 & & \\
\hline \multirow{3}{*}{$\begin{array}{l}\text { The lowest } \\
\text { result }\end{array}$} & Mean \pm SD & $\begin{array}{l}18.20 \pm \\
14.31\end{array}$ & $9.00 \pm 7.52$ & $5.33 \pm 2.42$ & $4.67 \pm 2.42$ & \multirow{3}{*}{$0.042 *$} & \multirow{3}{*}{0.092} \\
\hline & $\begin{array}{l}\text { Range } \\
\text { (Min - Max) }\end{array}$ & $5-37$ & $1-19$ & $2-8$ & $2-8$ & & \\
\hline & $\begin{array}{l}\text { Shapiro-Wilk } \\
\text { p-value }\end{array}$ & 0.226 & 0.872 & 0.484 & 0.484 & & \\
\hline \multirow{4}{*}{ IMA, \% } & Mean \pm SD & $48.33 \pm$ & $77.67 \pm$ & $86.11 \pm$ & $81.95 \pm$ & \multirow{4}{*}{0.061} & \multirow{4}{*}{0.083} \\
\hline & Range & 29.11 & 27.28 & 12.55 & 21.35 & & \\
\hline & (Min - Max) & $0-75.00$ & $33.33-100$ & $66.67-100$ & $50.00-100$ & & \\
\hline & $\begin{array}{l}\text { Shapiro-Wilk } \\
\text { p-value }\end{array}$ & 0.262 & 0.244 & 0.242 & 0.144 & & \\
\hline \multirow{3}{*}{$\begin{array}{l}\text { Results at } \\
\text { the main } \\
\text { competitions }\end{array}$} & Mean \pm SD & $\begin{array}{l}20.00 \pm \\
14.14\end{array}$ & $5.25 \pm 6.55$ & $1.50 \pm 0.55$ & $2.17 \pm 0.98$ & \multirow{3}{*}{$0.003^{*}$} & \multirow{3}{*}{0.077} \\
\hline & $\begin{array}{l}\text { Range } \\
\text { (Min - Max) }\end{array}$ & $10-30$ & $1-15$ & $1-2$ & $1-3$ & & \\
\hline & $\begin{array}{l}\text { Shapiro-Wilk } \\
\text { p-value }\end{array}$ & 1 & 0.074 & 0.010 & 0.047 & & \\
\hline
\end{tabular}

Note. Mean - arithmetic mean; SD - standard deviation; Max - the maximum in the season; Min - the minimum in the season; AP - "average place", the average mean of all places that athletes achieved in competitions during the season; IMA, "indicator of medal achievements" - the ratio of events in which athletes won medals to the total number of tournaments held by them during the season (\%); the highest/ the lowest results - the highest/ the lowest places which athletes achieved during the season; results at the main competitions - the places taken by athletes at the World Championships in $1^{\text {st }}-3^{\text {rd }}$ seasons (2013-2015), and the Games of XXXI Olympiads the $4^{\text {th }}$ season (2016); ${ }^{*}$ significantly different indicators $(p \leq 0.05)$.

which was heavier than the priority. Four more athletes missed the 2014 season for reasons unknown to us. Two of them performed exclusively in the age category "Juniors".

In 2015, majority of athletes $(n=14)$ performed exclusively in the Olympic WC. Four wrestlers combined performances in the Olympic and non-Olympic, giving preference to the first (50.00-71.43\% of events). The additional non-Olympic WC was heavier than the Olympic one. H. A. (Republic of Azerbaijan) performed mainly in the non-Olympic WC $(66.67 \%)$, using the heavier Olympic as an additional $(33.33 \%)$. H. Ya. from the Islamic Republic of Iran was limited to performances only in the non-Olympic WC. Three more wrestlers competed in two Olympic WCs, one of which (heavier) was a priority $(50.00-80.00 \%)$.

In 2016 , the majority of athletes $(79.17 \%, \mathrm{n}=19)$ performed only in the Olympic WC. Sh. Sh. (Republic of Azerbaijan) competed in two Olympic WCs (additional was heavier than priority). Interestingly, this WC was chosen as an athlete exclusively for performances at the Games of XXXI Olympiad 2016 (in previous seasons, he preferred to perform in the heavier Olympic WC). Three more athletes used the Olympic WC (50.00-75.00\% of 
Table 5. Tactics of weight category choice in elite freestyle wrestlers during the Olympic cycle of 2013-2016 $(n=24)$

\begin{tabular}{|c|c|c|c|c|c|c|c|c|}
\hline \multirow{4}{*}{ Type of Tactics } & \multicolumn{8}{|c|}{ Seasons } \\
\hline & 2013 & & 2014 & & 2015 & & 2016 & \\
\hline & \multicolumn{8}{|c|}{ Number of athletes } \\
\hline & Abs. & $\%$ & Abs. & $\%$ & Abs. & $\%$ & Abs. & $\%$ \\
\hline 0 & 17 & 70.83 & 15 & 62.50 & 14 & 58.33 & 19 & 79.17 \\
\hline $0+0$ & 1 & 4.17 & & & 3 & 12.50 & 1 & 4.17 \\
\hline $\mathrm{O}+\mathrm{N}$ & 1 & 4.17 & 4 & 16.67 & 4 & 16.67 & 3 & 12.50 \\
\hline $\mathrm{N}$ & & & & & 1 & 4.17 & & \\
\hline $\mathrm{N}+\mathrm{O}$ & & & 1 & 4.17 & 1 & 4.17 & & \\
\hline $\mathrm{N}+\mathrm{O}+\mathrm{O}$ & & & & & & & 1 & 4.17 \\
\hline Missed the season* & 5 & 20.83 & 4 & 16.67 & 1 & 4.17 & & \\
\hline
\end{tabular}

Note. Types of tactics: $\mathrm{O}$ - performances exclusively in one Olympic weight category (WC); $\mathrm{O}+\mathrm{O}-\mathrm{a}$ combination of performances in two Olympic WCs, one of which is a priority; $\mathrm{O}+\mathrm{N}$ - a combination of performances in two WC (Olympic and non-Olympic) with preference for the first; $\mathrm{N}$ - performances exclusively in one non-Olympic WC; $\mathrm{N}+$ $\mathrm{O}-\mathrm{a}$ combination of performances in two WC (non-Olympic and Olympic) with the preference of the first; $\mathrm{N}+\mathrm{O}+$ $\mathrm{O}-\mathrm{a}$ combination of performances in three WC (non-Olympic and two Olympic) with the preference of the first; $\mathrm{N}$ $+\mathrm{N}+\mathrm{O}-$ a combination of performances in three WC (two non-Olympic and one Olympic) with preference for one non-Olympic; Abs. - the number of wrestlers who used a certain type of tactics (absolute value); $\%$ - the number of wrestlers who used a certain type of tactics (percentage of the total number, $n=24$ ); ${ }^{*}$ - the number of wrestlers who did not take part in any official international event during the season.

events) as a priority, and the heavier non-Olympic - as an additional (33.33-50.00\%). The tactics of WC choice used by H. A. (Azerbaijan) deserve special attention. In the $4^{\text {th }}$ season, he preferred to perform in the non-Olympic $\mathrm{WC}$, occasionally performing in the heavier Olympic. However, in the Olympic arena, he performed in a lighter WC than the one that was chosen as a priority in previous seasons. Assume that, as in the case of Sh. Sh. the change of the priority WC exclusively for the performance at the Olympic Games was due to the deterioration of the results in the priority WC during the fourth season compared to the previous ones.

\section{Discussion}

Problems of tactics and tactical training are widely covered in the scientific literature [31-33]. Nevertheless, the interpretation of the term tactics is still the subject of scientific discussions [34-36]. Due to the lack of a unified approach to the interpretation of the term tactics, the study of its features in the system of competitions is the subject of a small number of research. Most of them are theoretical in nature $[5,8,16,37]$. In turn, the available empirical studies on wrestling take into account tactics at the level of the bout and its episodes [7, 35]. Given the above, the participation tactics of athletes in competition system requires proper scientific justification and more detailed study.

Our previous papers highlight the participation tactics of elite fencers [27]. The specifics of participation tactics during the Olympic cycle largely depend on the Olympic qualification criteria. Fencers are interested in participating in at least seven events in each season to improve or maintain their position in the official Rankings. Instead, there is no need for this in wrestling. First of all, the prospect of Olympic qualification in wrestling does not depend on the position in the official Rankings. It is important mainly for the draw before WCh, World Cup, Continental Championships, Ranking Series [28].

The obtained data allowed to find that elite freestyle wrestlers increase their competition practice during the $1^{\text {st }}-3^{\text {rd }}$ seasons, but decrease it in the $4^{\text {th }}$. Similar results were described by Latyshev and Tropin about GrecoRoman wrestling from 1993 to 2016 [17]. However, the number of competitions in their work is the sum of performances of all Olympic champions. It does not reflect the performances' dynamics during each season of the Olympic cycles.

Instead, we found that in 2013-2016, some wrestlers $(\mathrm{n}=9)$ missed a different number of seasons (from one to three). Three athletes did not take part in the WCh 2013-2015, but performed in official international events. According to our assumption, one of the reasons may be the change of sports citizenship in the current Olympic cycle, which did not allow to successfully pass the national selection and get into the national team. The reason for the omission of the $1^{\text {st }}$ and $2^{\text {nd }}$ seasons by $\mathrm{R}$. $\mathrm{H}$. from Japan could be a combination of performances in the age categories "Juniors" and "Seniors". The USA representative J. M. T. C., in 2013-2015 did not participate in any official international event, but in 2016 he became a leader and won awards in all competitions, including the Games of XXXI Olympiad.

Comparing the performance's dynamics and results of each athlete during the Olympic cycle allowed to identify different types of tactics for choosing the weight category (WC). Just like in women's wrestling, in freestyle wrestling in 2013 the boundaries of the WCs were changed, and new ones were added to the Olympic program [25]. In 
contrast to women's wrestling, the number of Olympic categories for men was reduced from seven to six. At the same time, at the $2013 \mathrm{WCh}$, men could compete in seven WCs, and in 2014-2015 - in eight (the non-Olympic WC "70 kg" was introduced in the competition program).

During 2013-2016 the most relevant tactics involved performances exclusively in the Olympic WC. In different seasons 58.33-79.17\% used it. In the 2014 and 2015, some wrestlers used different types of performances in other WCs, choosing one of them as a priority and one or two as additional. Interestingly, most athletes performed in those additional WCs that were heavier than the priority. Only three athletes competed in the additional WC, which was easier than the priority. This type of WC choice was used by M. I. I. in 2013, and in 2014 by Sh. Sh., In 2015 - I. $\mathrm{S}$. (Republic of Belarus). In the case of performances in several age categories, most athletes competed in similar WCs (WC limits for "Cadets" or "Juniors" coincided with WCs for "Seniors").

Comparison of the results with similar data in women's wrestling [38] indicated that during 2013-2016 both men and women used four types of participation tactics in the competition system: leadership holding, gradual increase of results, combined and leadership return.

The tactics of WC choice during the season provided for giving preference to performances in one prior WC. Most athletes chose the Olympic WC as a priority. Performances in additional WCs (Olympic or nonOlympic) were either absent or episodic (1-2 events per year). The same athletes used different tactics of WC choice depending on the place of the season in the fouryear Olympic cycle and the dynamics of sports results. Based on this, the following types of WC choice were identified:

1. Performances in one Olympic WC and in its updated version (after changes in the rules of UWW 2013) for four seasons. It was used by ten athletes.

2. Performances in several WCs (Olympic and nonOlympic) with the preference of the Olympic for several seasons or the whole cycle, including for performances at major competitions (WCh and Olympic Games). Performances in the non-Olympic WC were episodic - 1-2 events per season. This type of tactic was common to six athletes.

3. Performances in the non-Olympic and Olympic WC during the $1^{\text {st }}-3^{\text {rd }}$ seasons, preferring the non-Olympic, a full transition to the Olympic WC in the $4^{\text {th }}$ season. It was used by H. Ya. Ch. (Islamic Republic of Iran).

4. Performances in several Olympic WCs during a cycle or several seasons, preferring the one in which the highest results were demonstrated. It was used by three fighters.

5. Performances in non-Olympic and Olympic WCs during the $1^{\text {st }}-3^{\text {rd }}$ seasons, preferring non-Olympic, including. Performance in several Olympic WCs (heavier and lighter than non-Olympic) in the $3^{\text {rd }}$ or $4^{\text {th }}$ seasons and choosing the Olympic one with more prospects. Its elements were used by $\mathrm{H}$. A. (Azerbaijan Republic).

6. Performances in one priority Olympic WC during all seasons, and occasional performances in another Olympic WCs (1-2 tournaments per season) with demonstration of equally successful results in both WCs. Typical for A. S. (Russian Federation).

7. Performances in one priority Olympic WC throughout the cycle and a sudden choice of another WC only for performances in the Olympics due to the decrease of results in the $4^{\text {th }}$ season in the priority Olympic WC. In its "pure" form, this kind of tactic was typical for Sh. S., partly - for H. A. (both - representatives of the Republic of Azerbaijan).

8. Performances in one Olympic WC during the $1^{\text {st }}$ or $2^{\text {nd }}$ season, complete transition to another Olympic WC in the $3^{\text {rd }}$ or $4^{\text {th }}$ season with demonstration of equally successful performances in both WCs. It was used by A. S. (Romania).

Comparison of the obtained results with similar ones in women's wrestling [28] allowed to state that for men it was typical to use more types of tactics of WC choice during the Olympic cycle (six varieties were found among women). Most of the representatives of women's wrestling in 2013-2016 combined several types of tactics of choosing WC [28], and men preferred one of them.

In our opinion, the obtained results are relevant in the current Olympic cycle of 2016-2020. In 2017 in freestyle wrestling (men) there were introduced new WC. Their number in the program of competitions for the World Cup 2018 and 2019 was increased to ten. That's why WC choice still involves preferring the prior and, if necessary, one or two additional WC. Unfortunately, due to the global pandemic, the main part of the 2020 season was cancelled (including the World Olympic Qualifying Events). Therefore, it is impossible to make correct conclusions about the participation tactics during 20172020. However, given that the 2020 Olympic selection system has not changed much compared to the same in 2016 (except for the number of World Qualifying Events), we assume that the results can be extrapolated to the current Olympic cycle.

\section{Conclusions}

There are four types of participation tactics in the competition system in freestyle wrestling. In 2013-2016 Olympic cycle they included leadership holding, gradual increase of results, combined, leadership return. The main differences between types of tactics are the volume of competition practice, the dynamics of results, the choice of weight category. The most relevant was the type of tactics with performances exclusively in the Olympic weight category during four seasons.

\section{Conflict of interest.}

The authors declare no conflict of interest. 


\section{References}

1. Platonov VN. The system of athletes training in Olympic sports. General theory and its practical applications. Kiev: Olympic Literature; 2015. (In Russian).

2. Brzyski J. The individual offensive effectiveness of top level soccer players during an encounter and in close contact with an antagonist - secondary analysis based on the methodological criterion of the theory of combat sports. Archives of Budo Science of Martial Arts and Extreme Sports. 2016;12:77-86.

3. Keller VS. Study of the activity of athletes in variable conflict situations. Moscow: State Central Order of Lenin Institute of Physical Culture; 1975. (In Russian).

4. Malkov OB, Gozhin VV. The main components of the tactics of the fight in martial arts. Teoriia $i$ praktika fizicheskoj kul'tury, 2009; 2: 3-6. (In Russian).

5. Kamaev OI, Tropin IuN, Kostiukov IaE. Wrestling tactics. Martial arts, 2017; 2: 27-31. (In Russian).

6. PolikanovaI,Leonov S, IsaevA, Liutsko L. Individual Features in the Typology of the Nervous System and the Brain Activity Dynamics of Freestyle Wrestlers Exposed to a Strong Physical Activity (a Pilot Study). Behavioral Sciences. 2020;10(4). https://doi.org/10.3390/bs10040079

7. Chino K, Saito Y, Matsumoto S, Ikeda T, Yanagawa Y. Investigation of exercise intensity during a freestyle wrestling match. The Journal of Sports Medicine and Physical Fitness, 2015; 55(4): 290-6.

8. Tumanian GS. Champion training strategy. Soviet sport (Physical culture and sports); 2006. (In Russian).

9. Biac M, Hrvoje K, Sprem D. Beginning age, wrestling experience and wrestling peak performance-trends in period 2002-2012. Kinesiology. 2014; 46 (S-1):94-100.

10.Latyshev M, Latyshev S, Korobeynikov G, Kvasnytsya O, Shandrygos V, \& Dutchak Y. The analysis of the results of the Olympic free-style wrestling champions. Journal of Human Sport and Exercise. 2019; 5(2):400-410. https://doi.org/10.14198/jhse.2020.152.14

11. Worsey MTO, Espinosa HG, Shepherd JB, Thiel DV. Inertial Sensors for Performance Analysis in Combat Sports: A Systematic Review. Sports. 2019;7(1). https://doi.org/10.3390/sports7010028

12.Chernozub A, Korobeynikov G, Mytskan B, Korobeinikova L, Cynarski WJ. Modelling Mixed Martial Arts Power Training Needs Depending on the Predominance of the Strike or Wrestling Fighting Style. Ido Movement for Culture Journal of Martial Arts Anthropology, 2018:28-36. https://doi.org/10.14589/ido.18.3.5

13.Dudnyk O, Yarmak O, Dotsyuk L, Mykhaylyshyn G, Zoriy Y, Moseychuk J. Assessment of human psychophysiological responses to intense exercise: a survey of GrecoRoman wrestlers and unqualified competitors. Journal of Physical Education and Sport. 2017;17(3):2089-96. https://doi.org/10.7752/jpes.2017.s4212

14.Beránek V, Votápek P, Stastny P. Force and velocity of impact during upper limb strikes in combat sports: a systematic review and meta-analysis. Sports Biomechanics 2020:1-19. https://doi.org/10.1080/14763141.2020.1778075

15.Slimani M, Znazen H, Sellami M, Davis P. Heart rate monitoring during combat sports matches: a brief review. International Journal of Performance Analysis in Sport. 2018;18(2):273-292. https://doi.org/10.1080/24748668.2018.1469080

16.Abdullaiev AK, Rebar IV. Theory and methods of teaching freestyle wrestling. Melitopol: FOP Odnorog TV; 2018. (In Ukrainian).

17.Latyshev M, Tropin Y. Sports career analysis of olympic champions in Greco-Roman wrestling.
Martial Arts, 2020:22-34. (In Russian). https://doi.org/10.15391/ed.2020-1.03

18.Boguszewski D, Adamczyk JG, Boguszewska K, Wrzosek D, Mrozek N, Waloch $\mathrm{M}$, et al. Functional assessment of women practising combat sports and team sports using the Functional Movement Screen. Biomedical Human Kinetics. 2019;11(1):90-96. https://doi.org/10.2478/bhk-2019-0012

19.Krabben K, Orth D, van der Kamp J. Combat as an Interpersonal Synergy: An Ecological Dynamics Approach to Combat Sports. Sports Medicine. 2019;49(12):1825-1836. https://doi.org/10.1007/s40279-019-01173-y

20.Shadgan B, Feldman BJ, Jafari S. Wrestling injuries during the 2008 Beijing Olympic Games. Am J Sports Med, 2010; 38: 1870-1876. https://doi.org/10.1177/0363546510369291

21.Park S, Kim Y, Woo S, Lee O. A survey study on sports injury by age for male athletes in combat sports. Journal of Mens Health. 2021;17(2):120-126. https://doi.org/10.31083/jomh.2021.009

22.Witkowski K, Piepiora P, Gembalski K. Prevention and treatment of injuries sustained in combat sports by adolescents aged 15-16. Archives of Budo Science of Martial Arts and Extreme Sports. 2019;15:151-158.

23.Barbas I, Fatouros IG, Douroudos II, Chatzinikolaou A, Michailidis Y, Draganidis D, Katrabasas I. Physiological and performanceadaptationsofeliteGreco-Romanwrestlersduring a one-day tournament. Eur JAppl Physiol, 2011;111:1421-36. https://doi.org/10.1007/s00421-010-1761-7

24.Callan SD, Brunner DM, Devolve KL, Mulligan SE, Hesson J, Wilber RL, Kearney JT. Physiological profiles of elite freestyle wrestlers. J Strength Cond Res, 2000; 14: 162-9. https://doi.org/10.1519/00124278-200005000-00008

25.Mirzaei B, Moghaddam MG, \& Abadi HAY. Analysis of Energy Systems in Greco-Roman and Freestyle Wrestlers Who Participated in the 2015 and 2016 World Championships. InternationalJournalofWrestlingScience, 2017;7(1-2):35-40. https://doi.org/10.1080/21615667.2017.1394402

26.Shandrigos' VI, Latishev MV, Roztorguj MS, Pervachuk RV. Dynamics of the number of weight categories in women's wrestling. Martial arts. 2021; 1 (19): 79-89. (In Ukrainian) https://doi.org/10.15391/ed.2021-1.08

27.Zadorozhna O, Pityn M, Hlukhov I, Stepanyuk S, Kharchenko-Baranetska L, Drobot K. Indicators of athletes' effectiveness as a basis of team tactical training in women epee fencing. Trends in Sport Sciences. 2020; 27(4): 191-202. https://doi.org/10.23829/TSS.2020.27.4-2

28.United World Wrestling [Internet]. 2021. [updated 2029 Jan 15; cited 2021 May 10]. Available from: https:// unitedworldwrestling.org/

29. Shiian BM, Iedinak GA, Petrishin IuV. Scientific researches in physical education and sports: scientific manual. KamianetsPodilskyi: Printing House Ruta. 2012. (In Ukrainian).

30.Zadorozhnaya OR, Palatny AL, Bondarenko OV, Pitin MP. The attitude of freestyle wrestling specialists to the implementation of tactical training at different stages of longterm improvement of athletes. Naukovij chasopis, 2019; 7 (115): 39-44. (In Ukrainian).

31.Isik O, Cicioglu HI, Gul M, Alpay CB. Development of the Wrestling Competition Analysis Form According to the Latest Competition Rules. International Journal of Wrestling Science, 2017; 7(1-2): 41-5. https://doi.org/10.1080/21615667.2017.1422815

32.Tunnemann H, Curby DG. Scoring Analysis of the Wrestling from the 2016 Rio Olympic Games. International Journal of Wrestling Science, 2016; 6(2): 90-116. 
https://doi.org/10.1080/21615667.2017.1315197

33. Miarka B, dal Bello F, Brito CJ, Amtmann J. Technicaltactical ratios by round, genders and weight division of mixed martial arts for training. International Journal of Performance Analysis in Sport. 2018;18(1):78-89. https://doi.org/10.1080/24748668.2018.1447210

34.Lopez-Gonzalez DE. Technical Profile of Top Four Women's Wrestling Teams in the 2014 Senior World Championships and Correlations with Selected Performance Variables. International Journal of Wrestling Science, 2015; 5(1): 35-41. https://doi.org/10.1080/21615667.2015.1028124

35.Lopez-Gonzalez DE, Miarka B. Reliability of a new time-motion analysis model based on technical-tactical interactions for wrestling competition. International
Journal of Wrestling Science, 2013; 3(1): 21-34. https://doi.org/10.1080/21615667.2013.10878967

36.Gabyshev A, Cherkashin I, Cherkashina E. Mas-Wrestling is the National Sport of the Sakha Turkic People. Bilig. 2021(97):201-222.

37.Machado JC, Barreira D, Teoldo I, Travassos B, Bosco J, Dos Santos JOL, et al. How Does the Adjustment of Training Task Difficulty Level Influence Tactical Behavior in Soccer? Research Quarterly for Exercise and Sport. 2019;90(3):403-416. https://doi.org/10.1080/02701367.2019.1612511

38.Zadorozhna OR. Participation tactics of elite athletes in the competition system in women's wrestling during 2013-2016 Olympiccycle.MartialArts.2021;2(20):47-61.(InUkrainian). https://doi.org/10.15391/ed.2021-2.04

\section{Information about the authors:}

Olha R.Zadorozhna; (Corresponding Author); https://orcid.org/0000-0001-6318-1660; ozadorozhna@ukr.net; Department of Theory of Sports and Physical Culture, Lviv State University of Physical Culture named after Ivan Bobers'kyy; Lviv, Kostyushko, 11,79007 , Ukraine.

Yuriy A. Briskin; https://orcid.org/0000-0001-6375-9872; yuriy.briskin@gmail.com; Department of Theory of Sports and Physical Culture, Lviv State University of Physical Culture named after Ivan Bobers'kyy; Lviv, Kostyushko, 11, 79007, Ukraine.

Maryan P. Pityn; https://orcid.org/0000-0002-3537-4745; pityn7@gmail.com; Department of Theory of Sports and Physical Culture, Lviv State University of Physical Culture named after Ivan Bobers'kyy; Lviv, Kostyushko, 11, 79007, Ukraine.

Viktoriia Yu. Bohuslavska; https://orcid.org/0000-0003-3609-5518; Vik.bogusl@gmail.com; Department of Theory and Methods of Sports, Vinnytsia State Pedagogical University named after Mykhailo Kotsyubynsky; Vinnytsya, Ostroz'kogo, 32, 21001, Ukraine.

Ivan G. Hlukhov; https://orcid.org/0000-0003-4226-5253; swim.ks.ua@gmail.com; Department of Theory and Methodology of Physical Education, Kherson State University; Kherson, Univerditets'ka, 27, 73000, Ukraine.

Cite this article as:

Zadorozhna OR, Briskin YA, Pityn MP, Bohuslavska VYu, Hlukhov IG. Participation tactics of elite freestyle wrestlers in competition system in 2013-2016 Olympic cycle. Pedagogy of Physical Culture and Sports, 2021;25(5):275-285. https://doi.org/10.15561/26649837.2021.0502

This is an Open Access article distributed under the terms of the Creative Commons Attribution License, which permits unrestricted use, distribution, and reproduction in any medium, provided the original work is properly cited (http://creativecommons.org/licenses/by/4.0/deed.en).

Received: 14.05.2021

Accepted: 18.06.2021; Published: 30.10.2021 